\title{
Article
}

\section{Student Perspectives on Curricular Change: Lessons from an Undergraduate Lower-Division Biology Core}

\author{
Merri Lynn Casem
}

\author{
Department of Biological Science, California State University, Fullerton, CA 92834-9480
}

Submitted June 27, 2005; Accepted September 15, 2005

Monitoring Editor: Erin Dolan

\begin{abstract}
Inquiry-based laboratories are acknowledged as the preferred method of instruction for development of research skills. Much has been written about changes in student performance associated with inquiry, but less is known about how students view the inquiry-based format or whether they perceive a benefit from this type of instruction. The Student Assessment of Learning Gains (SALG) survey was used to evaluate and compare student reactions to the new, inquiry-based laboratories of a lower-division undergraduate curriculum, from implementation to the present (an interval of $3 \mathrm{yr}$ ). Initial student response to the format and value of the inquiry labs improved over time. The quality of the graduate teaching assistants and the clarity of the laboratory manual were important variables influencing student perception. A student's perception of his/her retention of lab-related skills was strongly associated with perceptions of gains in those skills. Student responses reflect their most current laboratory experience and not a cumulative effect of participation in the core series of courses. Student success in the inquiry format was not associated with gender or status as a transfer student. The majority of students believe that their experiences in the lower-division inquiry labs have prepared them for upper-division course work.
\end{abstract}

\section{INTRODUCTION}

Inquiry-based laboratory instruction has been a cornerstone of the curricular reforms proposed for improving the recruitment and retention of undergraduate science majors (Boyer, 1998; National Research Council, 2003). Reform of introductory courses is seen as being especially important for the retention of underrepresented students in science and mathematics (Seymour and Hewitt, 1997; Labov, 2004). Inquiry is a key pedagological feature of $\mathrm{K}-12$ science education as well (National Research Council, 1996). Inquirybased laboratories feature opportunities for students to pose research questions, formulate hypotheses, and devise tests of those hypotheses (Handelsman et al., 2004; Howard and Miskowski, 2005). Students engage in a more authentic experience of the scientific process, including data analysis and various forms of scientific communication. Although the adoption of an inquiry-based laboratory format may have clear goals and benefits from the perspective of the instructor, the students who must engage with the curricu-

DOI: $10.1187 /$ cbe. $05-06-0084$

Address correspondence to: Merri Lynn Casem (mcasem@ fullerton.edu). lum are unlikely to share this perspective (Glasson and McKenzie, 1998). Furthermore, the implementation of a new format of instruction may create unforeseen consequences. Ultimately, the success of such curricular reform efforts must be measured both by the "consumer satisfaction" expressed by the students and by the achievements of these students in other courses, especially in the upper-division course offerings of the major (Luckie et al., 2004). The response of students to these reform initiatives has not, to date, been well represented in the literature (Temple and Loesser, 2002; Howard and Miskowski, 2005).

This study examines the reaction of students to the adoption of an inquiry-based lab format in a series of lower-division core courses for the biology major. Student assessment of their lab experiences is compared from the initial implementation of the inquiry format, to the present, a period of six semesters.

\section{History}

Beginning in 1997, faculty members in the Department of Biological Science, California State University, Fullerton (CSUF), began a discussion of how to reform the existing core curriculum to enhance student preparation for upper-division course work, improve retention of students in the biology major, and streamline progression through the major. 
The original core series of courses required for biology majors included both lower-division and upper-division courses. The first course in the major was a lower-division, survey-type course with no associated lab. Students then completed courses in zoology, botany, cellular biology, genetics, ecology, and microbiology. Some of these courses included a laboratory class, whereas others offered the laboratory as a separate course. Students frequently completed courses out of sequence or did not complete the core before beginning their upper-division electives. Consequently, students in upper-division courses lacked a common set of experiences on which to build their knowledge and skills.

The department initiated a reform of the core curriculum with support from the National Science Foundation (DUE 9950835 and DUE 0127167). The new core curriculum consists of four lower-division courses, each with a laboratory. They are Biodiversity and Evolution, Cellular Biology, Genetics and Molecular Biology, and Principles of Physiology and Ecology. The courses are built around a set of student learning outcomes with an instructional design that emphasizes studentcentered learning. The biological themes of Unity and Diversity, Evolution, and System Dynamics, as well as the perspectives of the Process of Science and Human Impact on Biological Systems, are embedded in all four courses. The laboratories associated with the core courses are inquirybased, including a mix of both guided and open or fullinquiry. Guided-inquiries involve students in directed activities associated with instructor-defined research questions. Guided-inquiries are also used as introductions to a model system and/or experimental techniques. In contrast, openinquiries require that students pose their own research questions, develop their own hypotheses, and plan and implement a research protocol (including controls) where the outcome of the experiment is not predetermined. In both types of inquiry activities, students collect and analyze data using the appropriate statistical tests and report their findings in a scientific format. A summary of the number and type of inquiry activities used throughout the lower-division core are provided (Table 1). In addition, the labs were designed with the intention of providing progressive skill development across the four core courses. Students are required to complete the core series in sequence. Articulations have been made with local community colleges to allow for transfer into the core. The first three core courses (Biodiversity and Evolution, Cellular Biology, and Genetics and Molecular Biology) were implemented in the Fall 2002 semester. The final core course was implemented in the Spring 2003 semester.

On completion of the lower-division core, students begin their upper-division electives in the major. As of the Fall 2004 semester, students are required to declare an emphasis within the biology major, choosing from the following: Biodiversity, Ecology $\mathcal{E}$ Conservation, Marine Biology, Cell $\mathcal{E}$ Developmental Biology, or Molecular Biology E Biotechnology. Each emphasis consists of an intermediate or "gateway" course, as well as a diverse collection of recommended courses. All biology majors must complete five upper-division laboratory or field units. At a minimum, this requirement is typically met through the completion of three or more upperdivision courses with an associated laboratory, although some students also receive credit for independent research.

\section{Demographics}

CSUF is one of the largest of the 23 campuses in the California State University system. Within the Department of Biological Science, $\sim 75 \%$ of the more than 700 undergraduate majors describe themselves as minority or multiethnic, with Hispanics contributing $25 \%$ to the student population. Women outnumber men, $62 \%$ to $38 \%$. Approximately $70 \%$ of the biology majors pursue careers in allied health. CSUF is an urban "commuter" campus. Seventy-five percent of our students work, and more than $65 \%$ of entering students are community college transfers. The average age of our majors is 22 years old. Over $50 \%$ of students at our university come from families in which neither parent graduated from college, $26 \%$ are first-generation college students, and $13 \%$ come from families in which neither parent has a high school diploma. English is a second language for $46 \%$ of CSUF students (www. fullerton.edu/analytical studies; accessed 6/14/05).

\section{METHODS}

Data on student reaction to the implementation of a new series of lower-division core courses has been collected for Biodiversity $\mathcal{E}$ Evolution, Cellular Biology, and Genetics \& Molecular Biology, starting with the first semester of implementation, to the present (Spring 2005). Data for Principles of Physiology \& Ecology were not collected until the fourth semester after implementation. Student reaction to the courses in general, and the format of the inquiry-based labs in particular, was measured using the Student Assessment of Learning Gains (SALG), a free, online survey instrument originally developed by Elaine Seymour and currently available through the Wisconsin Center for Educational Research (www.wcer.wisc.edu/salgains/instructor/). The site provides a generic template that can be customized to meet the needs of a specific course. Surveys were constructed (in collaboration with the faculty associated with the lowerdivision core) to assess student perceptions of their learning gains relative to course-specific student learning outcomes for both lecture and laboratory, as well as departmental-level learning outcomes related to critical thinking, information competency/library research skills, and themes within the biology major. The survey consists of five main questions related to 1) how specific aspects of the course have helped a student's learning, 2) how well students think they understand specific course concepts, 3) the degree to which the course has added to a student's skills, 4) the extent to which students believe they have made specific gains as a result of the course, and finally, 5) the degree to which students believe they will retain skills or knowledge. The survey allows for the creation of additional questions outside the standard template. The reliability and validity of the SALG survey have been established (Seymour et al., 2000). Samples of these surveys are available on the SALG Web site (www.wcer.wisc.edu/salgains/instructor/; enter as "Guest"; then go to "See Examples").

Students were asked, as a part of their normal participation in a course, to respond to a series of overarching questions dealing with how much the instructional design of the course helped the student learn, the degree to which the course added to the student's skills in specific areas, and how much the student anticipates they will retain from the course. The structure of the SALG survey asks students to rank the value of specific features of their lab experience, using a five-point scale where 5 represents "very helpful" / "a great deal," 4 is "much help" /"a lot," 3 is "moderate help" /" somewhat," 2 is "a little help" / "a little," and 1 reflects an assessment of "no help" / not at all." Students also responded to demographic questions and provided open-text responses to questions about their lab experience. The surveys are password protected and all responses are anonymous, although the SALG site does provide a record of the number and identity of respondents, separate from the actual sur- 
Table 1. Summary of the inquiry-based laboratories in the lower-division core

\begin{tabular}{|c|c|c|c|}
\hline Biodiversity \& Evolution & Cellular Biology & Genetics \& Molecular Biology & Principles of Physiology \& Ecology \\
\hline $\begin{array}{l}\text { How to design an experiment } \\
\text { ( } 1 \text { wk). Students observe the } \\
\text { behavior of isopods and } \\
\text { then develop a hypothesis, } \\
\text { design and carry out their } \\
\text { own experiments. They then } \\
\text { communicate their results } \\
\text { through oral presentations. }\end{array}$ & $\begin{array}{l}\text { Skills module ( } 5 \mathrm{wk} \text { ). Students } \\
\text { are introduced to basic } \\
\text { laboratory skills in cell } \\
\text { biology such as microscopy, } \\
\text { aseptic technique, and } \\
\text { spectrophotometry through } \\
\text { the use of guided inquiry } \\
\text { activities. This module } \\
\text { culminates with a skills } \\
\text { practicum. }\end{array}$ & $\begin{array}{l}\text { Mendelian genetics (semester } \\
\text { long). Students explore the } \\
\text { concepts of homozygosity } \\
\text { and heterozygosity through } \\
\text { the development of } \\
\text { hypotheses related to the } \\
\text { outcome of dihybrid } \\
\text { crosses of Fast Plants. Chi- } \\
\text { square analysis is used to } \\
\text { validate predictions. }\end{array}$ & $\begin{array}{l}\text { Introduction (1 wk). Students } \\
\text { develop and test hypotheses about } \\
\text { the relationships between diverse } \\
\text { objects. Emphasis is on the use of } \\
\text { numerical data and statistics. }\end{array}$ \\
\hline $\begin{array}{l}\text { Artificial selection (semester } \\
\text { long). Students identify } \\
\text { variable traits in a small } \\
\text { population of plants. } \\
\text { Students learn about plant } \\
\text { life cycles as they select, } \\
\text { cross-pollinate, and grow } \\
\text { multiple generations of Fast } \\
\text { plants. Students record and } \\
\text { analyze the effects of } \\
\text { selection. Results are } \\
\text { reported in standard } \\
\text { scientific format. }\end{array}$ & $\begin{array}{l}\text { Cell signaling ( } 5 \text { wk). Students } \\
\text { engage in } 2 \text { wk of guided } \\
\text { inquiry introducing a } \\
\text { bacterial chemotaxis assay, } \\
\text { flagellar regrowth assay, and } \\
\text { pollen tube growth assay. } \\
\text { This is followed by } 2 \text { wk of } \\
\text { student-generated open } \\
\text { inquiry using these systems } \\
\text { and techniques including data } \\
\text { analysis and interpretation. } \\
\text { The final week is used for } \\
\text { oral presentations. }\end{array}$ & $\begin{array}{l}\text { DNA replication (5 wk). } \\
\text { Students gain skills in gel } \\
\text { electrophoresis, PCR, } \\
\text { restriction digest, and } \\
\text { cloning. Students predict } \\
\text { the outcomes of restriction } \\
\text { digestions based on } \\
\text { hypotheses specific to the } \\
\text { vector, primer, and } \\
\text { directionality of the } \\
\text { insertion used. Students } \\
\text { report their findings either } \\
\text { as a poster or oral } \\
\text { presentation. }\end{array}$ & $\begin{array}{l}\text { Energetics ( } 3 \text { wk). Students learn } \\
\text { techniques to measure energy } \\
\text { production or expenditure for } \\
\text { plants and animals and then devise } \\
\text { hypotheses to compare between } \\
\text { physiologically diverse groups (C3 } \\
\text { vs. C4, endotherm vs. ectotherm). } \\
\text { Students prepare reports in } \\
\text { standard scientific format. }\end{array}$ \\
\hline $\begin{array}{l}\text { Biodiversity modules ( } 7 \mathrm{wk}+ \\
\text { field trips). Students observe } \\
\text { organisms and develop } \\
\text { testable hypotheses related } \\
\text { to patterns within multiple } \\
\text { ecosystems (desert, rocky } \\
\text { inter-tidal, coastal sage } \\
\text { scrub, etc). In addition, } \\
\text { students compile a } \\
\text { biodiversity log examining } \\
\text { the natural history of a } \\
\text { species. }\end{array}$ & $\begin{array}{l}\text { Energy and enzymes ( } 5 \mathrm{wk}) \text {. } \\
\text { Students participate in } 2 \mathrm{wk} \\
\text { of guided inquiries assaying } \\
\text { catalase activity, isolating } \\
\text { chloroplasts, and assaying } \\
\text { photosynthetic activity. This } \\
\text { is followed by } 2 \text { wk of } \\
\text { student-generated open } \\
\text { inquiry using these systems } \\
\text { and techniques and } 1 \text { wk of } \\
\text { presentations. }\end{array}$ & $\begin{array}{l}\text { Differential gene expression } \\
\text { (4 wk). Students devise } \\
\text { tests of inducible gene } \\
\text { expression using transgenic } \\
\text { plants. Students make } \\
\text { prediction of patterns of } \\
\text { gene expression based on } \\
\text { hypotheses specific to the } \\
\text { types of promoters used. } \\
\text { Students are encouraged to } \\
\text { evaluate and revise their } \\
\text { experimental protocol. }\end{array}$ & $\begin{array}{l}\text { Desert behavior ( } 3 \text { wk + field trip). } \\
\text { Students learn behavioral } \\
\text { techniques as part of guided } \\
\text { inquiry followed by open inquiry } \\
\text { related to the behavior of desert } \\
\text { organisms. This module involves } \\
\text { an overnight field trip. Students } \\
\text { report in standard scientific format. }\end{array}$ \\
\hline $\begin{array}{l}\text { Conservation ( } 2 \text { wk }+ \text { field } \\
\text { trip). Students engage in a } \\
\text { guided inquiry to examine } \\
\text { the impact of fire on a } \\
\text { habitat. Students measure } \\
\text { and analyze variation in } \\
\text { plant cover, plant diversity, } \\
\text { or insect diversity. Results } \\
\text { are presented orally. }\end{array}$ & & $\begin{array}{l}\text { Human genetics ( } 4 \mathrm{wk}) \text {. } \\
\text { Students examine the } \\
\text { principles of transmission } \\
\text { of autosomal dominant and } \\
\text { X-linked traits through } \\
\text { guided inquiries using } \\
\text { web-based and database } \\
\text { resources. Results are } \\
\text { presented in either a poster } \\
\text { or oral format. }\end{array}$ & $\begin{array}{l}\text { Protist population ( } 3 \mathrm{wk}) \text {. Students } \\
\text { design their own experiments to } \\
\text { test the effects of competition, } \\
\text { predation, and population growth } \\
\text { among protists. Students prepare } \\
\text { individual reports following } \\
\text { standard scientific format. }\end{array}$ \\
\hline $\begin{array}{l}\text { Introduction to microbes (1 } \\
\text { wk). Students examine } \\
\text { microbial diversity using } \\
\text { environmental sampling and } \\
\text { cell counting techniques. } \\
\text { This guided inquiry allows } \\
\text { students to explore the } \\
\text { question of where microbes } \\
\text { are in the environment. }\end{array}$ & & $\begin{array}{l}\text { Ethics in molecular biology (4 } \\
\text { wk). Students debate social } \\
\text { issues related to advances } \\
\text { in molecular biology. } \\
\text { Students are responsible } \\
\text { for identifying, accessing, } \\
\text { and synthesizing } \\
\text { information relative to the } \\
\text { positions of various } \\
\text { stakeholders. The debate } \\
\text { includes oral presentations } \\
\text { and rebuttal. }\end{array}$ & $\begin{array}{l}\text { Foothill vegetation ( } 2 \mathrm{wk}+\text { field } \\
\text { trip). In this guided-inquiry activity } \\
\text { students compare vegetation on } \mathrm{N} \\
\text { vs. S facing slopes, then generate } \\
\text { hypotheses for particular species or } \\
\text { groups of species of plants based } \\
\text { on their understanding of plant } \\
\text { morphology and physiology. } \\
\text { Students prepare group reports } \\
\text { following standard scientific } \\
\text { format. }\end{array}$ \\
\hline
\end{tabular}

vey results. Students were awarded a small number of points toward their final course grade for completing the survey. Collection and analysis of survey data were completed in compliance with the guidelines for use of human subjects (CSUF-HSR 2684).
Survey results are compiled by the Web site, both as frequency tables and means with standard deviations. Pair-wise comparisons of the means for different courses or different semesters of the same course were made using a two-tailed $t$ test. The $t$ test requires a 
minimum sample size of 50 . This requirement was met in all but two cases. Comparison of the means across all four core courses was made using a one-way ANOVA, based on the means and standard deviations provided from the SALG site (Zar, 1999). The SALG program also allows faculty to construct contingency tables (crosstabs). The significance of the association between two variables within the survey was tested using chi-square. Gamma was then calculated for each statistically significant relationship as a measure of the strength of the association between the two variables. All tests of statistical significance were made at an $\alpha$ level of 0.05 .

\section{RESULTS}

The demographic profile of students enrolled in the lowerdivision core courses varied slightly over the semesters examined (Table 2). The gender ratio and numbers of transfer students were fairly consistent over time. Class standing (years in college) showed the greatest variation from the first semester of implementation to the most recent semester. The number of students completing the core in sequence is approaching $100 \%$. Student participation in the survey has been very good, with the exception of the Fall 2002 assessment of the first core course, Biodiversity and Evolution.

Student reaction to the instructional design of the inquirybased laboratories for each of the core courses was assessed (Table 3). Students enrolled in a course during the first semester of implementation typically gave significantly lower ratings to the organization and activities associated with the labs than did the students in subsequent semesters. A comparison of the most recent surveys for the four courses reveal continuing differences in student ranking of the organization $(F(3,401)=2.62, p<0.05)$ and the lab manual $(F(3,401)=6.62, p<0.001)$ but no significant difference in perceptions of the value of the inquiry format $(F(3,401)=$ $1.62, p<0.2)$. Strong, positive relationships exist between a student's perception of the inquiry format and his/her assessment of the organization of the labs ( $d f 16, \chi^{2}=498, p<$ $0.001, \gamma=0.97)$, the value of the graduate teaching assistants' lecture and instructions $\left(d f 16, \chi^{2}=298, p<0.001, \gamma=\right.$ 0.96 ), and the ability to design and test hypotheses ( $d f 16$, $\left.\chi^{2}=475, p<0.001, \gamma=0.97\right)$. Conversely, a student's attitude toward the format of the inquiry labs was positively influenced by the perceived quality of the graduate teaching assistant (df 16, $\left.\chi^{2}=183, p<0.001, \gamma=0.94\right)$ and the quality of the laboratory manual ( $d f 16, \chi^{2}=226, p<0.001, \gamma=$ $0.84)$. No relationship was found to exist between the level of a student's academic experience (years in college), transfer status, or gender and his/her perception of the educational value of the format or organization inherent in the modified laboratory curriculum either initially or after six semesters of implementation (data not shown).

Students report gains in their evaluation of lab-related skill development, ranging between "somewhat" to "a lot," across all categories and courses (Table 4). Student perceptions of gains were less during the first semester of implementation in almost every case where data were available. Pair-wise comparison of survey results from Fall 2002 and Spring 2005 semesters of the second core course (Cellular Biology) revealed statistically significant differences in the areas of finding references to the primary literature ( $d f 210$, $t=4.37, p<0.001)$ and experimental design $($ df 210, $t=2.18$, $p<0.05)$. Comparisons of the responses from students across the span of all four core courses for Spring 2005 showed significant differences in the areas of hypothesis generation $(F(3397)=3.74, p<0.01)$, finding references $(F(3397)=5.67, p<0.001)$, statistical analysis $(F(3397)=$ 43.16, $p<0.001)$, graphing $(F(3397)=9.84, p<0.01)$, and oral $(F(3397)=16.19, p<0.001)$ and written $(F(3397)=9.44$, $p<0.001)$ communication skills. The relationship between

Table 2. Demographics for the lower-division core biology series

\begin{tabular}{|c|c|c|c|c|c|c|c|c|}
\hline & \multicolumn{2}{|c|}{ Biodiversity \& Evolution } & \multicolumn{2}{|c|}{ Cellular Biology } & \multicolumn{2}{|c|}{$\begin{array}{c}\text { Genetics \& Molecular } \\
\text { Biology }\end{array}$} & \multicolumn{2}{|c|}{$\begin{array}{c}\text { Principles of Physiology } \\
\text { \& Ecology }\end{array}$} \\
\hline & Fall 2002 & Spring 2005 & Fall 2002 & Spring 2005 & Fall 2002 & Spring 2005 & Fall 2004 & Spring 2005 \\
\hline \multicolumn{9}{|l|}{ Year in college } \\
\hline 1st & 58 & 42 & 0 & 41 & 2 & 2 & 0 & 0 \\
\hline 2nd & 18 & 15 & 17 & 21 & 5 & 19 & 2 & 7 \\
\hline 3rd & 20 & 26 & 39 & 22 & 12 & 35 & 16 & 44 \\
\hline 4th & 2 & 10 & 28 & 8 & 38 & 16 & 36 & 29 \\
\hline 5th or more & 2 & 8 & 16 & 9 & 43 & 29 & 47 & 21 \\
\hline \multicolumn{9}{|l|}{ Gender } \\
\hline Female & ND & 56 & ND & 61 & ND & 52 & 71 & 61 \\
\hline Male & ND & 44 & ND & 39 & ND & 48 & 29 & 39 \\
\hline \multicolumn{9}{|l|}{ Transfer student } \\
\hline Yes & ND & 30 & ND & 31 & ND & 26 & 39 & 29 \\
\hline No & ND & 70 & ND & 69 & ND & 74 & 61 & 71 \\
\hline \multicolumn{9}{|l|}{ Prior core course } \\
\hline One & NA & NA & NA & 100 & NA & 19 & 4 & 1 \\
\hline Two & NA & NA & NA & 0 & NA & 68 & 32 & 7 \\
\hline Three & NA & NA & NA & 0 & NA & 13 & 64 & 92 \\
\hline Percent respondents & 7 & 82 & 93 & 90 & 100 & 84 & 79 & 100 \\
\hline
\end{tabular}

Demographic data were collected from the SALG survey for the semesters indicated. Values are proportions for each course expressed as percentages. ND, not determined; NA, not applicable. 
students' perception of the quality of their graduate teaching assistant relative to their gain in general laboratory skills showed a stronger positive relationship during the first semester of implementation ( $d f 16, \chi^{2}=37.5, p<0.01, \gamma=$ $0.98)$ versus the most recent semester ( $d f 16, \chi^{2}=84.7, p<$ $0.001, \gamma=0.61$ ), The relationship between perceived quality of the teaching assistant and skill development in the other categories listed in Table 4 was found to be positive, but weak (data not shown). Students' class standing, transfer status, or gender was not significantly associated with their responses to skill development (data not shown).

Student perceptions of their retention of various laboratory skills were also examined (Table 5). A strong correlation was found to exist between student perceptions of gain and their estimation of retention specific to skills in ability to access scientific information from primary and secondary sources (df 16, $\left.\chi^{2}=420, p<0.001, \gamma=0.99\right)$, experimental design ( $d f 16, \chi^{2}=325, p<0.001, \gamma=0.83$ ), statistical

Table 3. How much did each of the following aspects of the class help your learning?

\begin{tabular}{|c|c|c|c|c|c|c|c|c|}
\hline & \multicolumn{2}{|c|}{$\begin{array}{l}\text { Biodiversity \& } \\
\text { Evolution }\end{array}$} & \multicolumn{2}{|c|}{ Cellular Biology } & \multicolumn{2}{|c|}{$\begin{array}{c}\text { Genetics \& Molecular } \\
\text { Biology }\end{array}$} & \multicolumn{2}{|c|}{$\begin{array}{c}\text { Principles of Physiology } \\
\text { \& Ecology }\end{array}$} \\
\hline & Fall 2002 & Spring 2005 & Fall 2002 & Spring 2005 & Fall 2002 & Spring 2005 & Fall 2004 & Spring 2005 \\
\hline The format of the labs & ND & $3.74(0.97)$ & ND & $3.54(0.96)$ & ND & $3.50(1.02)$ & $3.34(1.08)$ & $3.49(0.90)$ \\
\hline $\begin{array}{l}\text { Organization of the lab } \\
\text { modules* }\end{array}$ & $3.29(0.96)$ & $3.8(0.97)$ & $2.5(1.14)$ & $3.6(0.99)^{* *}$ & $2.88(1.02)$ & $3.4(1.09)^{* *}$ & $3.38(1.19)$ & $3.55(1.05)$ \\
\hline $\begin{array}{l}\text { Ability to design and test } \\
\text { your own hypotheses }\end{array}$ & $2.93(0.8)$ & $3.78(0.93)$ & $2.98(1.22)$ & $3.49(0.96)^{* *}$ & $3.03(0.88)$ & $3.55(0.91)^{* *}$ & $3.72(1.14)$ & $3.72(0.97)$ \\
\hline Presentations in lab & $2.93(1.03)$ & $3.56(1.04)$ & $3.3(1.29)$ & $3.46(1.07)$ & $3.23(1.03)$ & $3.4(0.99)$ & $3.34(1.21)$ & $3.71(0.9)$ \\
\hline The lab manual ${ }^{* * *}$ & $3.62(1.15)$ & $3.87(0.86)$ & $2.42(1.12)$ & $3.61(0.98)^{* *}$ & $3.19(1.14)$ & $3.41(0.97)$ & $3.37(1.07)$ & $3.29(1.0)$ \\
\hline $\begin{array}{l}\text { Teaching assistant } \\
\text { lectures and } \\
\text { instructions }\end{array}$ & ND & $3.9(0.97)$ & ND & $3.73(1.18)$ & ND & $3.92(1.05)$ & ND & $3.81(0.94)$ \\
\hline $\begin{array}{l}\text { Amount and quality of } \\
\text { contact with your } \\
\text { teaching assistant }\end{array}$ & $3.64(1.04)$ & ND & $3.25(1.25)$ & $3.86(1.04)$ & $4.29(0.84)$ & $3.76(1.1)^{* *}$ & $3.64(1.04)$ & $3.93(0.98)$ \\
\hline $\begin{array}{l}\text { No. of students } \\
\text { completing the survey }\end{array}$ & 14 & 90 & 112 & 103 & 65 & 120 & 46 & 92 \\
\hline
\end{tabular}

Data were collected from SALG surveys administered during the semesters indicated. Values are means, with SD in parentheses. ND, not determined.

${ }^{*} p<0.05,{ }^{* * *} p<0.001$ for one-way ANOVA comparing Spring 2005 survey data across all four courses.

** $p<0.001$ for two-tail $t$ test comparing means of the first semester of implementation and the most recent semester.

Table 4. How much has this class added to your skills in each of the following?

\begin{tabular}{|c|c|c|c|c|c|c|c|c|}
\hline & \multicolumn{2}{|c|}{$\begin{array}{l}\text { Biodiversity \& } \\
\text { Evolution }\end{array}$} & \multicolumn{2}{|c|}{ Cellular Biology } & \multicolumn{2}{|c|}{$\begin{array}{c}\text { Genetics \& Molecular } \\
\text { Biology }\end{array}$} & \multicolumn{2}{|c|}{$\begin{array}{c}\text { Principles of Physiology } \\
\text { \& Ecology }\end{array}$} \\
\hline & Fall 2002 & Spring 2005 & Fall 2002 & Spring 2005 & Fall 2002 & Spring 2005 & Fall 2004 & Spring 2005 \\
\hline $\begin{array}{l}\text { Devising a test for a } \\
\text { hypothesis* }\end{array}$ & ND & $3.6(1.01)$ & ND & $3.66(0.93)$ & ND & $3.61(0.89)$ & $3.65(1.0)$ & $3.99(0.93)$ \\
\hline Finding references ${ }^{* *}$ & ND & $3.64(1.03)$ & $3.03(0.98)$ & $3.62(1.0)^{* * *}$ & ND & $3.33(0.97)$ & $3.57(1.1)$ & $3.89(0.94)$ \\
\hline General lab skills & $3.43(0.90)$ & $3.75(1.07)$ & ND & $3.95(0.96)$ & 3.78 (1.03) & $3.81(0.88)$ & $3.43(1.06)$ & $3.71(0.89)$ \\
\hline Designing lab experiments & $3.71(0.88)$ & $3.67(1.01)$ & $3.52(1.08)$ & $3.82(0.91)^{* * * *}$ & $3.6(0.91)$ & $3.66(0.89)$ & $3.52(1.08)$ & $3.89(0.91)$ \\
\hline Statistical analysis** & ND & $3.64(1.13)$ & ND & $3.63(0.9)$ & ND & $3.45(1.02)$ & $4.0(0.98)$ & $4.18(0.86)$ \\
\hline $\begin{array}{l}\text { Graphing data and } \\
\text { interpreting graphs }\end{array}$ & ND & $3.67(1.02)$ & ND & $3.78(0.95)$ & ND & $3.44(1.0)$ & $3.89(1.15)$ & $4.15(0.84)$ \\
\hline $\begin{array}{l}\text { Working effectively with } \\
\text { others }\end{array}$ & ND & $3.77(1.13)$ & $3.74(1.13)$ & $4.01(0.91)$ & ND & $3.69(0.99)$ & $3.7(1.12)$ & $3.91(0.90)$ \\
\hline Giving oral presentations ${ }^{* *}$ & ND & $3.61(0.99)$ & $3.75(1.14)$ & $3.68(0.96)$ & ND & $3.76(0.90)$ & $3.67(1.02)$ & $4.04(0.84)$ \\
\hline $\begin{array}{l}\text { Writing in a scientific } \\
\text { format** }^{* *}\end{array}$ & ND & $3.72(0.95)$ & ND & $3.59(1.0)$ & ND & $3.52(0.92)$ & $3.96(1.11)$ & $4.15(0.86)$ \\
\hline $\begin{array}{l}\text { No. of students completing } \\
\text { the survey }\end{array}$ & 14 & 88 & 110 & 102 & 65 & 120 & 46 & 91 \\
\hline
\end{tabular}

Data were collected from SALG surveys during the semesters indicated. Values are means, with SD in parentheses. ND, not determined. ${ }^{*} p<0.01,{ }^{* *} p<0.001$ for one-way ANOVA comparing Spring 2005 survey data across all four courses.

${ }^{* * *} p<0.001,{ }^{* * * *} p<0.05$ for a two-tail $t$ test comparing means from Fall 2002 and Spring 2005 for the second course. 
analysis (df 16, $\left.\chi^{2}=249, p<0.001, \gamma=0.89\right)$, scientific writing ( $d f 16, \chi^{2}=464, p<0.001, \gamma=0.86$ ), and oral communication ( $d f 16, \chi^{2}=318, p<0.001, \gamma=0.77$ ). Comparison of student responses across the most recent four lower-division core courses, however, demonstrated significant differences in the areas of accessing scientific information $(F(3398)=3.39, p<0.02)$, statistical analysis $(F(3398)=$ 8.34, $p<0.001)$, and oral $(F(3398)=2.62, p<0.05)$ and written $(F(3398)=4.16, p<0.01)$ communication skills. Students' participation within the core (i.e., the number of courses they had completed) was strongly associated with their ranking of retention of their skills in accessing scientific information ( $d f 16, \chi^{2}=27.5, p<0.05, \gamma=0.92$ ). None of the other lab skills showed a significant relationship with experience in the core (data not shown). Retention of lab skills is not related to class standing, transfer status, perceived quality of the teaching assistant, or gender (data not shown). A moderately positive relationship was found to exist, however, between students' attitude toward their teaching assistant and their likely retention of the ability to work cooperatively with others $\left(d f 16, \chi^{2}=73.6, p<0.001\right.$, $\gamma=0.54)$, and to appreciate the lab and field aspects of biology (df 16, $\left.\chi^{2}=77.3, p<0.001, \gamma=0.50\right)$ and the dynamic nature of scientific inquiry $\left(d f 16, \chi^{2}=59.8, p<\right.$ $0.001, \gamma=0.53$ ).

A novel aspect of the inquiry labs of this lower-division core series has been the inclusion of a common model organism in each of the courses. Wisconsin Fast Plants have been adapted to illustrate relevant course concepts across all four lower-division courses, with the goal of both giving students practice in the care and handling of the organism, as well as creating a context for students to gain insights into the unity and diversity of biological systems. Although the majority of students in the final core course reported that the use of the Fast Plants throughout the core was helpful to their learning $(3.74 \pm 0.95)$, there was no significant relationship between the perceived value of the model organism and student confidence in their ability to work with plants or animals in a laboratory setting.

Student assessment of their preparation for upper-division laboratory work was examined for those students enrolled in the final core course during the Spring 2005 semester (Table 6). Students ranked their overall preparation between "a fair amount," and "a great deal." Over $80 \%$ of the students expressed confidence in their abilities to work with plants, animals, and bacteria. Students were also con-

Table 5. How much of the following do you think you will remember and carry with you?

\begin{tabular}{|c|c|c|c|c|c|c|c|c|}
\hline & \multicolumn{2}{|c|}{$\begin{array}{l}\text { Biodiversity \& } \\
\text { Evolution }\end{array}$} & \multicolumn{2}{|c|}{ Cellular Biology } & \multicolumn{2}{|c|}{$\begin{array}{c}\text { Genetics \& Molecular } \\
\text { Biology }\end{array}$} & \multicolumn{2}{|c|}{$\begin{array}{l}\text { Principles of Physiology } \\
\text { \& Ecology }\end{array}$} \\
\hline & Fall 2002 & Spring 2005 & Fall 2002 & Spring 2005 & Fall 2002 & Spring 2005 & Fall 2004 & Spring 2005 \\
\hline $\begin{array}{l}\text { Ability to access scientific } \\
\text { information* }\end{array}$ & ND & $3.68(0.95)$ & $3.6(1.0)$ & $3.74(1.01)$ & ND & $3.5(0.95)$ & $4.07(0.98)$ & $3.92(0.92)$ \\
\hline Skills in designing experiments & ND & $3.63(0.89)$ & $3.83(1.05)$ & $3.85(0.86)$ & ND & $3.71(0.86)$ & $4.0(0.97)$ & $3.91(0.88)$ \\
\hline $\begin{array}{l}\text { Skills in statistics and data } \\
\text { analysis** }\end{array}$ & ND & $3.6(0.95)$ & $3.57(1.07)$ & $3.79(0.90)$ & ND & $3.52(0.86)$ & $4.09(1.11)$ & $4.11(0.89)$ \\
\hline Oral communication skills*** & ND & $3.67(0.93)$ & $3.67(1.0)$ & $3.69(1.04)$ & ND & $3.76(0.97)$ & $3.96(1.09)$ & $4.02(0.84)$ \\
\hline Scientific writing skills ${ }^{* * * *}$ & ND & $3.67(0.92)$ & $3.8(0.98)$ & $3.7(0.95)$ & ND & $3.58(0.91)$ & $4.18(1.05)$ & $4.02(0.92)$ \\
\hline $\begin{array}{l}\text { Making critical observations and } \\
\text { translating them into testable } \\
\text { hypotheses }\end{array}$ & ND & $3.81(0.92)$ & ND & $3.79(0.86)$ & ND & $3.77(0.90)$ & $4.0(1.0)$ & $3.96(0.86)$ \\
\hline $\begin{array}{l}\text { No. of students completing the } \\
\text { survey }\end{array}$ & & 90 & 109 & 102 & & 120 & 45 & 90 \\
\hline
\end{tabular}

Data were collected from the SALG surveys for the semesters indicated. Values are means, with SD in parentheses. ND, not determined. ${ }^{*} p<0.02,{ }^{* *} p<0.001,{ }^{* * *} p<0.05,{ }^{* * *} p<0.01$ for one-way ANOVA comparing Spring 2005 survey data across all four courses.

Table 6. Student assessment of their preparation for upper-division lab work

How prepared are you for work in an upper-division lab class? $4.25 \pm 0.7$

Knowledge of the diversity of organisms and Very confident

Confident the function of their body systems

Ability to work with plants or animals in a field setting

Ability to work with plants or animals in a lab setting
Ability to work with bacterial cultures

\begin{tabular}{lccc}
23 & 57 & 19 & 1 \\
24 & 56 & 18 & 2 \\
33 & 52 & 13 & 1 \\
33 & 51 & 16 & 0 \\
\hline
\end{tabular}

Data were collected from the SALG survey for the core course Principles of Physiology E Ecology during the Spring 2005 semester. Values are percentages. $\mathrm{n}=91$. 
fident in their knowledge of the diversity of organisms and the function of their body systems.

The influence of the lab experience on a student's perception of gains related to the themes and perspective for the lowerdivision core was examined (Table 7). Once again, student responses varied across the four courses, with significant differences occurring in the areas of appreciation of diversity $(F(3399)=4.33, p<0.005)$, understanding the dynamic nature of biological systems $(F(3399)=3.91, p<0.009)$, awareness of how the process of evolution influences biology $(F(3399)=3.3$, $p<0.02)$, and awareness of the impact of humans on biological systems $(F(3399)=7.76, p<0.001)$.

\section{DISCUSSION}

The goal of this article is to add a new perspective on the process of inquiry-based curricular reform: that of the students. As educators and scientists, we can appreciate the value of early research experiences, and we can recognize the order and organization of an introductory biology curriculum. Our students, on the other hand, are simply trying to pass our courses to move into the upper division and finally to graduate in the major. The Student Assessment of Learning Gains survey instrument has proved to be a very useful tool for examining both the immediate and ongoing student reaction to curricular reform. The high percentage of student participation in the survey supports the overall ease of use of this instrument and suggests that the cumulative results accurately reflect the opinions of a diversity of students.

Changes to the instructional design of a course (or series of courses) influence the educational experience and expectations of the students enrolled in those courses (Harrison et al., 2001; Russell and French, 2002; Luckie et al., 2004). How did our students react to the inquiry-based laboratories?
Initial student response was less than positive. Students at all levels in the major gave low marks to the organization and activities of the inquiry-based labs, suggesting that intellectual maturity is not a replacement for familiarity (Perry, 1998). In some cases, lower rankings were also given for questions related to the students' assessment of their gain in laboratory skills during the first semester of implementation. Overall, student perspectives on their laboratory skill development have averaged between "somewhat" and "a lot" on the five-point scale, although significant differences remain between some courses, especially the final core course.

Consistent with the findings of Howard and Miskowski (2005), students report that the inquiry-based format of the labs is of "moderate" to "much" help to their learning. A student's perception of the inquiry format is an excellent predictor of his/her perception of the overall educational value of the organization and activities associated with the laboratories. Student comments reveal enthusiasm for the opportunity to "create our own experiments." However, frustration with the quality of the laboratory manual and the effectiveness of some graduate teaching assistants are also expressed (see Appendix).

A key finding that emerges then from these results is that the student's perceptions regarding the graduate teaching assistants used in the laboratory sections is an important variable that influences student perception of the format and educational value of the inquiry lab experience. The influence of the teaching assistant on student perception of skill development was very strong during the first semester of implementation and remains significant after six semesters. Students' perceptions of the teaching assistant also appear to influence their perceptions of long-term skills in group work and their appreciation for the process of scientific discovery and its role in biology. Teaching assistants, just like their students, must adapt to the different instructional approach

Table 7. Student gains in the themes and perspectives for the lower-division core

\begin{tabular}{|c|c|c|c|c|}
\hline $\begin{array}{l}\text { Awareness of how all living } \\
\text { things are similar }\end{array}$ & $3.96(0.99)$ & $3.86(0.9)$ & $3.66(0.99)$ & $3.82(0.87)$ \\
\hline $\begin{array}{l}\text { Appreciation of the diversity } \\
\text { of living things* }\end{array}$ & $4.01(0.94)$ & $3.78(0.98)$ & $3.57(1.07)$ & $3.93(0.85)$ \\
\hline $\begin{array}{l}\text { Understanding the dynamic } \\
\text { nature of biological } \\
\text { systems }\end{array}$ & $3.79(0.9)$ & $3.54(0.92)$ & $3.56(1.03)$ & $3.91(0.77)$ \\
\hline $\begin{array}{l}\text { Understanding the process of } \\
\text { scientific discovery }\end{array}$ & $3.79(0.94)$ & $3.54(0.83)$ & $3.6(0.96)$ & $3.79(0.88)$ \\
\hline $\begin{array}{l}\text { Awareness of the impact of } \\
\text { humans on biological } \\
\text { systems }\end{array}$ & $3.98(0.98)$ & $3.49(0.99)$ & $3.62(1.01)$ & $4.05(0.82)$ \\
\hline
\end{tabular}

Data were collected from SALG surveys during the Spring 2005 semester. Values are means, with SD in parentheses.

${ }^{*} p<0.01,{ }^{* *} p<0.02,{ }^{* * *} p<0.001$ for one-way ANOVA comparing Spring 2005 survey data across all four courses. 
required by the inquiry format. Faculty support of the professional development of teaching assistants is one way to facilitate sustained quality within a course (Glasson and McKenzie, 1998; Sundberg et al., 2000; Russell and French, 2002). It is interesting to note that the highest rating for the question "amount and quality of contact with your teaching assistant" (Table 3) occurred during a semester in which a faculty member taught in the laboratories.

Similarly, the quality of the laboratory manual also contributes to student perceptions of the course. Poor ratings and negative comments regarding the laboratory manual for the cellular biology course led to multiple revisions with a concomitant improvement in the numeric ranking. A positive relationship exists between students' perception of the lab manual and their assessment of the organization of the lab, although this relationship is not as strong as that between the lab manual and the inquiry format.

Do students perceive a value to the inquiry laboratory format? Over $50 \%$ of students surveyed $(234 / 452)$ in the most recent semester identified lab and field activities as the best form of instruction for the development of analytical and critical scientific thinking skills. Furthermore, $70 \%$ of students express the opinion that the expectations of the inquiry-based labs of the lower-division core were appropriate. It is not surprising to find, in this context, that students give high marks for laboratory skill development and retention. The especially strong student ranking for "gains in skills" and "retention of skills" in the physiology and ecology course may reflect differences in the type and frequency of activities within the lab. Students in this course, in particular, completed more writing, graphing, and statistical analysis assignments than did students in the preceding courses. The influence of the type and frequency of assignments in lab may also account for the changes in student perception of their skills in accessing scientific information in the cellular biology course. During the initial implementation of the cellular biology labs, library research skills were introduced, but not emphasized. In the current design of the labs, these skills are used multiple times throughout the semester.

The original design of the lower-division lab series sought to allow for the development of fundamental laboratory skills through introduction and repetition of those skills across all four courses, with the goal of enhancing student retention of those skills and thereby improving a student's preparation for upper-division course work. Did our students perceive an improvement of their retention of skills as a consequence of their participation in the core laboratories? Although students in the final core course reported that they would retain "somewhat" to "a lot" of the skills associated with the inquiry labs, cross-tabulation analysis revealed that this assessment was more strongly associated with students' perception of their gain in skills versus the number of other core lab courses in which they participated. By the fourth course (Principles of Physiology $\mathcal{E}$ Ecology), some students comment on the "repetitive" nature of the labs; however, other students recognize the repetition as a means of "skill building" and comment that their experiences in the laboratories of the lower-division core have prepared them for upper-division course work (see Appendix). Skill in finding and accessing scientific information was the only exception, with its strong association to experience in the core. This observation may be a consequence of the emphasis on the identification and use of primary and secondary literature that occurs in the first two courses.

The lack of a significant association between gender and the various aspects of the instructional design and educational value of these labs is a positive result, suggesting that the format of these labs is inclusive, an important feature for retention of students in the major (Seymour and Hewitt, 1997; Russell and French, 2002; Brueckner and Traurig, 2003). Likewise, the apparent lack of negative impact on our transfer student population suggests both that these courses provide sufficient support for these students and that the local community colleges are doing a very good job in preparing their students for articulation with our program.

One of the unique features of the lower-division core laboratories has been the inclusion of a common model organism throughout all four courses. The Wisconsin Fast Plants are a highly adaptable model organism (Williams and Hill, 1986; Wisconsin Fast Plants Program, 2005) used to highlight concepts related to artificial selection, pollen tube growth, Mendelian genetics, and gas exchange. The idea behind this approach was that iterative exposure to a model organism would enhance student skills in the care and manipulation of the organism while providing an example of how the seemingly diverse concepts of biology can be synthesized within a single organism. The majority of students reported that the use of the Fast Plants was a "fair amount" of help in their learning; however, there was no correlation between students' attitude about the value of the model organism and their confidence in their ability to work with plants in a laboratory or field setting. Several students commented negatively about the repetitive use of Fast Plants, whereas only one student recognized the value of familiarity with the system (see Appendix).

One of the major goals for the reform of the core laboratory curriculum has been to enhance student preparation for upper-division course work. Average student response to the question "how prepared are you for work in an upperdivision lab class?" was equivalent to a ranking between "a fair amount" and "a great deal." The majority of students $(\geq 80 \%)$ report that they are confident in their abilities to work in the upper division. Inquiry-based laboratory instruction has been found to enhance content knowledge (Russell and French, 2002). Surprisingly, no relationship was found between students' experience in the core and their level of confidence, suggesting that the rigor of the Principles of Physiology \& Ecology course may be influencing students' perceptions. However, anecdotal information provided by faculty teaching in the upper division suggests that students leaving the lower-division core are manifesting stronger research and scientific communication skills. Further research will be required to confirm these observations.

The courses of the lower-division core provide contentspecific illustrations of the larger biological themes of unity and diversity, evolution, and systems dynamics using the perspectives of the process of science and the impact of humans on biological systems. The integration of these themes throughout the core appears to have influenced student awareness. Not surprisingly, students give their highest ranking of the themes of unity and diversity and evolution during the semester in which they are enrolled in the course, Biodiversity and Evolution. Similarly, students rank 
their understanding of the dynamic nature of biological systems and awareness of the impact of humans on biological systems highest during their semester in Principles of Physiology and Ecology. The absence of any significant difference in student ranking of awareness of the similarity of living things or the process of science suggests that all courses are meeting the goal of providing some reasonable level of exposure to the themes throughout the core curriculum.

In conclusion, our students appear to perceive the benefit of the inquiry format and express support for the opportunity to participate in laboratory activities that mirror the authentic process of scientific discovery (Roth, 1993; Luckie et al., 2004; Howard and Miskowski, 2005). However, negative comments continue to be expressed regarding the quality of the laboratory manual or the teaching assistants (see Appendix). Professional development of the teaching staff and the creation of quality laboratory materials and assignments therefore are important components to ensure success in the adoption of an inquiry-based laboratory pedagogy. Student responses to these survey instruments appear to reflect their most recent experiences. It may be necessary to use other means of assessment to identify any cumulative effects of participation in the core series of labs. Finally, "student assessment of learning gains" is not the same as objective assessment of student performance. The ultimate benefit of the reforms outlined in this work will be established by the evaluation of student performance in the upper-division course work and retention of students within the major.

\section{ACKNOWLEDGMENTS}

We acknowledge the instructional faculty for the lower-division biology core series in the Department of Biological Science, CSUF for their assistance in the development and administration of the SALG survey. This work was made possible through grant support from the National Science Foundation (DUE 0127167 and DUE 0127828).

\section{REFERENCES}

Brueckner, J. K., and Traurig, H. (2003). Students' responses to the introduction of a digital laboratory guide in medical neuroscience. Medical Teacher 25, 643-648.

Boyer, E. L. (1998). The Boyer commission on educating undergraduates in the research university, reinventing undergraduate education: a blueprint for America's research universities. Stony Brook, NY. http:/ / naples.cc.sunysb.edu/pres/boyer.nsf (accessed 20 May 2005).

Glasson, G. E., and McKenzie, W. L. (1998). Investigative learning in undergraduate freshman biology laboratories. J. College Sci. Teaching 27, 189-193.
Handelsman, J., et al. (2004). Scientific teaching. Science 304, 521522.

Harrison, J. F., Nichols, J. S., and Whitmer, A. C. (2001). Evaluating the impact of physical renovation, computerization, and use of an inquiry approach in an undergraduate, allied health human anatomy and physiology lab. Adv. Physiol. Educ. 25, 202-210.

Howard, D. R., and Miskowski, J. A. (2005). Using a module-based laboratory to incorporate inquiry into a large cell biology course. Cell Biol. Educ. 4, 249-260.

Labov, J. B. (2004). From the National Academies: the challenges and opportunities for improving undergraduate science education through introductory courses. Cell Biol. Educ. 3, 212-214.

Luckie, D. B., Maleszewski, J. J., Loznack, S. D., and Krha, M. (2004). Infusion of collaborative inquiry throughout a biology curriculum increases student learning: a four-year study of "Teams and Streams." Adv. Physiol. Educ. 287, 199-209.

National Research Council (2003). Bio 2010, Transforming undergraduate education for future research biologists. Committee on Undergraduate Education to Prepare Research Scientists for the 21st Century. Washington, DC: National Academies Press. www. nap.edu/books/0309085357/html (accessed 23 June 2005).

National Research Council (1996). National Science Education Standards Center for Science, Mathematics and Engineering Education, Washington, DC: National Academy Press.

Perry, W. G. (1998). Forms of Intellectual and Ethical Development in the College Years: A Scheme, San Francisco: Jossey-Bass.

Roth, W. M. (1993). The development of science process skills in authentic context. J. Res. Sci. Teaching 30, 127-152.

Russell, C. P., and French, D. P. (2002). Factors affecting participation in traditional and inquiry-based laboratories: a description based on observations and interviews. J. College Sci. Teaching 31, 225-229.

Seymour, E., and Hewitt, N. M. (1997). Talking about Leaving: Factors Contributing to High Attrition Rates among Science, Mathematics, and Engineering Undergraduate Majors, Boulder, CO: Bureau of Sociological Research.

Seymour, E., Wiese, D. J., and Hunter, A.-B. (2000). Creating a better mousetrap: on-line student assessment of their learning gains. www.aacu-edu.org/issues/sciencehealth/Mousetrap.pdf (accessed 28 May 2005).

Sundberg, M. D., Armstrong, J. E., Dini, M. L., and Wischusen, E. W. (2000). Some practical tips for instituting investigative biology laboratories, the nuts and bolts of successful laboratory instruction. J. College Sci. Teaching 29, 353-359.

Temple, J. G., and Loesser, K. E. (2002). Student perceptions of inquiry-based and traditional laboratory exercises in an undergraduate physiology course. Am. Zool. 41, 1605.

Williams, P. H., and Hill, C. B. (1986). Rapid-cycling populations of Brassica. Science 232, 1385-1389.

Wisconsin Fast Plants Program (2005). Wisconsin Fast Plant Home Page. www.fastplants.org (accessed 20 June 2005).

Zar, J. H. (1999). Biostatistical Analysis, Upper Saddle River, NJ: Prentice Hall. 


\section{Appendix SAMPLE COMMENTS}

The following student comments were extracted verbatim from the open-text response sections of various SALG surveys. Not all courses provided open-text responses for each semester. The course and semester associated with each comment is indicated in italics.

\section{Comments about the format of the labs}

"Self learning. The modules were placed on us to learn and discover-it was like real science!" Cellular Biology Fall 2002

"Having a directed experiment before being able to design own experiment is excellent because it helps students to become familiar with the concepts of each lab module." Cellular Biology Fall 2002.

"i would like the lab to be a little better structured so that i understand why i am being asked to perform the experiments and what i am supposed to gain from doing so." Cellular Biology, Fall 2002

"i really thought that although the instruction was a little bit vague, the non-detailed structure allowed us to learn on our own and really grasp the concepts." Cellular Biology, Fall 2002

"Dealing with real life stuff like DNA and genetic diseases. Things that relate to real life are always interesting to learn about. Do lab techniques that we read about, PCR, enzyme digestions." Genetics and Molecular Biology, Fall 2002.

"The experiments need to be modified so that some of them have a better probability of comming out." Genetics and Molecular Biology, Fall 2002

"The organization needs to be better. It is not the fault of the instructor, it's just because this is the first time this lab is being taught and we are the guinea pigs." Genetics and Molecular Biology, Fall 2002

"I felt like I didn't have any direction, I understand that most labs were meant NOT to be 'cook booked' but this resulted in disorganization and confusion with concepts." Biodiversity and Evolution, Spring 2005

"It would be better if the labs were connected to the lecture part of the course. For example, if we were learning about enzymes in lecture then we would be doing experiments in lab dealing with enzymes, at the same frame." Cellular Biology, Spring 2005

"I now know how to properly use a microscope. Designing our own experiments was very helpful because it forces you to apply what you have learned and it teaches you the scientific process involved and how to improve your experiments based on what you've learned. I also learned how to write an abstract." Cellular Biology, Spring 2005

"The lab helps me to understand and remember the concepts of biology more because I was involved in the activities and see how everything reacted." Cellular Biology, Spring 2005

"I felt that this lab was somewhat unorganized. There was not enough time for the second module and felt the first one could have been shortened since the material is not as intense. In the second module, we were rushing just to get things done that I didn't feel I had an understanding of what was going on." Genetics and Molecular Biology, Spring 2005

"Lab was made much worce because it very difficult to understand what exactly was expected of us. Trying to get the lab instructor (Chue) to explain to us what was expected of us was like pulling teeth. This lab by far was the most poorly organized lab" Genetics and Molecular Biology, Spring 2005

"The labs of the lower division core are a joke. In lower division courses labs should be very structured to begin with, and then by the end they should be more free form. It does no good to throw people into something that they might not be familiar with." Principles of Physiology and Ecology, Fall 2004

"I plan on entering the teaching field and the activities and methods of how we tested our hypotheses, will be very useful for me in the future when I enter the field. I also enjoyed giving presentations because it helped me to be more comfortable using terminology and also helped me practice explaining biological concepts to others." Principles of Physiology and Ecology, Fall 2004

"The ability to observe and test hypothesis on the biodiversity and the reasons for the biodiversity of these organisms has changed my ideals on running experiments in lab as a learning mechanism. In this lab, we were actually able to make up our own experiments in order to test them. They had no known ending unlike other labs, making the experiments less exciting. Writing papers also greatly changed. Instead of one scientific paper for the semester, this class challenged me to write 3 . This helped me feel more confident about my biological writing skills." Principles of Physiology and Ecology, Spring 2005

"I liked the labs very much. I liked learning different techniques of how scientists analyze different things. I liked learning about gel electrophoresis, bacterial plating and gram-staining, etc. I think that the labs were necessary for me to get the hands on experience and they were a lot of fun too. I especially liked taking the field trips." Principles of Physiology and Ecology, Spring 2005

"it is easiest for me to understand a concept when it can be applied, therefore any hands-on experience that I was able to get, was the greatest help to me." Principles of Physiology and Ecology, Fall 2004

\section{Comments about the teaching assistants}

"I like the way the TA's explain the lab assignment a little more and give us background information on the lab." Biodiversity and Evolution, Fall 2002

"Actually have the lab TA's know what is going on and be able to answer all questions that students have." Cellular Biology, Fall 2002

"I would like more guidelines. I felt that sometimes the TA's were out of their league and this would frustrate them." Cellular Biology, Fall 2002

"The lab was not very helpful. My lab TA did not do a good job, and left many students clueless throughout the semester." Cellular Biology, Spring 2005

"The TA was a great help in clarifying the material." Genetics and Molecular Biology, Spring 2005

"The lab sucked. Our TA was very unfair with her grading. She was very unclear" Genetics and Molecular Biology, Spring 2005 
"I had a very great experience with Lab. The lab instructor was great. He is an outstanding teacher and makes the lab very interesting. The lab was hard, however he made it easy to understand and was always there when we had problems or questions." Principles of Physiology and Ecology, Fall 2004

\section{Comments about the laboratory manual}

"Be more organized; especially the lab manual. Everything was pretty much scattered, we had to flip back and forth to look up stuff." Cellular Biology, Fall 2002

"PLEASE get rid of the useless manual. Or make some major changes. It will be helpful to future students if the manual is more like the Chemistry manual." Cellular Biology, Fall 2002

"WHere do I begin? The TA was not very good and the labs were poorly organized. The poor organization was a direct result of the poor organization in the lab manual." Cellular Biology, Fall 2002

\section{Comments on skill development and retention}

"lab was very helpful and gave us much pratice on how to analyze observations." Cellular Biology, Spring 2005

"Many of the skills such as ablity to conduct skill anaylsis was covered in previous courses, thus some of the concepts presented in 172 built on these skills" Cellular Biology, Spring 2005

"i made most of the graphs my group used. $i$ think that skill will be the thing that carries with me most" Cellular Biology, Spring 2005

"Oral presentations taught me to become more confident in my oral skills, I don't get nearly as nervous as I used to in front of the class." Genetics and Molecular Biology, Spring 2005

"MY oral communication skills have increased thanks to the process learned during the preparation of presentations." Genetics and Molecular Biology, Spring 2005

"I learned a lot in lab that will probably stick with me towards my other laboratory classes in the future." Genetics and Molecular Biology, Spring 2005

"I'm not sure if I learned any particularly marketable skills in this class that would help in the biotech field" Genetics and Molecular Biology, Spring 2005

"All the labs helped be grow as a biology student." Genetics and Molecular Biology, Spring 2005

"The written report is very helpful. I help me to be a better writer. before this class i hated writing lab reports but now it's not so difficult causenot so bad after all." Principles of Physiology and Ecology, Fall 2004

"As this class falls at the end of my academic career statistical lessons learned here will not be well carried beyond this course. Other components of the class such as oral communication skills and appreciation of biodiversity I feel are life long learning aspects of the course that will remain active parts of my life beyond graduation." Principles of Physiology and Ecology, Spring 2005

"The knowledge I gained in this class, I know will help me in other classes. Before taking this class, I had very little knowledge of statistics. I knew how to do t-tests, but I had not had enough practice using them. This class strengthened my stat skills." Principles of Physiology and Ecology, Spring 2005

"Having taken three other core classes, I am able to continue my lab skills, and learn something new in each class. So, a lot of the things we learned this semester are being re-applied from previous ones." Principles of Physiology and Ecology, Spring 2005

"some of the skills have already been learned, and this course has reinforced some of those skills." Principles of Physiology and Ecology, Spring 2005

"I'm basing the following responses on the oral presentations. 171 only had 1 (if I recall correctly) and I thought that was really hard! When I took 172 , we had a few more and it was overwhelming. It wasn't that bad because 171 prepped me for it. 273 had even more presentations than the other two but they weren't that bad because I was already used to it. In regards to everything else, the labs were fine in general. Working in the field is the best way for me to learn." Principles of Physiology and Ecology, Spring 2005

"With the lower division core labs, I am confident about formulating and testing experiiments, being able to analyze graphs, tables, and data, writing scientific papers, communicating these ideas through oral presentations. I have also grown better at keeping records in a lab notebook." Principles of Physiology and Ecology, Spring 2005

\section{Comments on the use of Wisconsin Fast Plants}

"the Fast plants were extremely helpful in understanding gentics" Principles of Physiology and Ecology, Fall 2004

"A different plant should be chosen for each biol course. many students are very tired with working with the fast plants. from biol 171, 172,273 it gets repetitive. I think for genetics it is good because it grows fast and the lab that deals with the plant fits brassica rapa, but for 171 and 172 , something else needs to become part of the lab." Principles of Physiology and Ecology, Spring 2005

"A lot of the lower division core classes used the Wisconsin Fast Plant, so it was beneficial to be able to work with a plant that we are already very aquainted to." Principles of Physiology and Ecology, Spring 2005

"The fast plants are good at what they do, but the organism focused on should be one that is exciting and attentiongrabbing." Principles of Physiology and Ecology, Spring 2005 